\title{
Evaluation of oxathiapiprolin for the management of grapevine Downy mildew
}

\author{
I. Voiculescu ${ }^{1 *}$, A. Pantazi ${ }^{1}$ and R. Goguţ ${ }^{1}$ \\ ${ }^{1}$ Research and Development Institute for Viticulture and Oenology \\ Valea Calugareasca, Romania \\ *Corresponding author email: voiculescuioan@yahoo.com
}

\begin{abstract}
Downy mildew is a yield-limiting disease of grapevine, caused by the pathogen Plasmopara viticola. Oxathiapiprolin, the first member of the piperidinyl thiazole isoxazoline fungicides, was evaluated for efficacy on downy mildew in a field trial conducted in 2021 at the Research and Development Institute for Viticulture and Oenology Valea Calugareasca. Throughout the study, the rate range was narrowed from active ingredient (a.i.) at $200+1600$ to $85+85 \mathrm{~g}$ a.i. to an optimal effective rate of $20+1000 \mathrm{~g}$ a.i./ha. Within that optimal range, the downy mildew incidence treated with oxathiapiprolin and competitive commercially available fungicides was significantly lower than the incidence in the nontreated grapevine with disease pressure. There were no significant differences in the efficacies of product Zorvec (oxathiapiprolin+folpet, co pack) $(97,7-98,6 \%)$ and the standard fungicide Profiler (fluopicolide+fosetyl-aluminum), (96.9-97.8\%). To avoid the development of resistant strains and at the same time to enhance efficacy, in the field, with favorable weather conditions for pathogen growth, two resistance management practices were considered: (I) a preventive foliar application, forecast (to determine the spray timing), with use the fungicides, typically used in IPM, only in tank mixtures or pre-packs; (II) an eradicative foliar application of the systemic fungicides with the purpose off cure existing infections.
\end{abstract}

Keywords: vineyard, preventive, fungicide, disease, active ingredient

\section{INTRODUCTION}

Plasmopara viticola (Berk. \& Curt.) Berl. \& Toni., the causal agent of grapevine downy mildew, is a highly destructive pathogen on cultivated grapevine worldwide and may result in poor fruit set and fruit quality (Hewitt and Pearson, 1988). Oxathiapiprolin, is a new crop protection chemical (Bitner R.J., and Mila A.L. 2017; Pasterix R.J. et al., 2016) and it is authorized under the brand name Zorvec active. Downy mildew is a plant pathogen accepted as showing a high risk of development of resistance to fungicides in field conditions. In many vineyards located in regions of Romania, as many as 8-10 applications of fungicides are required to control this pathogen. Fungicide resistance is the naturally occurring, inheritable adjustment in the ability of individuals in a population to survive, a plant-protection product treatment that would normally give effective control (OEPP/EPPO, 1997). From a resistance management perspective, a larger number of applications and/or a higher dose are expected to increase the rate of selection for fungicide resistance (van den Bosch et al., 2011). 
There are three components, fungicide types, timing and technique (spray coverage and dose), which must be of good quality for good management of a disease.

\section{MATERIALS AND METHODS}

\section{Locations, experimental design and applications}

Seven treatments were conducted in commercial vineyards ('Sauvignon' cv.) at Research and Development Institute for Viticulture and Oenology - Valea Calugareasca, 2021, to evaluate the efficacy of oxathiapiprolin. All treatments within the trial were evaluated in a randomized complete block design with four replications, according to EPPO methods. Individual treatment blocks size was $25 \mathrm{~m}^{2}$. The plants were treated in accordance with the guidelines EPPO/OEPP PP 1/31 (3) (EPPO, 1997). The experiment was performed according to IPM guidelines (Malavolta and Boller, 2009). The experimental fungicide treatments were carried out from the beginning of the season, depending on the phenological stage, the infection rate in the control plots, and weather forecast (Meier, 2001). The application details of fungicide treatments (date, product name, rate, and active ingredient) to control downy mildew are listed (Table 1). The rates were those indicated by the manufacturer of the formulated products. Treatments were carried out using a motorized knapsack sprayer (Solo Port 423, Germany) by thoroughly wetting the grapevine plants (water volume: 1000 liter/ha).

Table 1. Dates, product names, rates, and active ingredients of fungicide treatments

\begin{tabular}{|c|c|c|}
\hline Product name & $\begin{array}{c}\text { Rate } \\
\mathrm{L} ; \mathrm{kg} / \mathrm{ha}\end{array}$ & Active ingredient \\
\hline S5K22 510SC & 2.0 & oxathiapiprolin $10 \%+$ folpet $80 \%$ ); \\
\hline UBL47 340SE & 0.5 & oxathiapiprolin $17 \%$ +zoxamide $17 \%$ \\
\hline QGU42 100OD + & $0.2+$ & $\begin{array}{c}\text { oxathiapiprolin } 10 \%+ \\
\text { folpet } 80 \%\end{array}$ \\
\hline Folpan WDG & 1.25 & folpet 80 \\
\hline Folpan WDG & 1.25 & fluopicolid $4.44 \%+$ fosetil-Al $66,7 \%$ \\
\hline Profiler 71,1 WG & 3 & dimetomorph $9 \%+$ mancozeb $60 \%$ \\
\hline Acrobat MZ 69 WG & 2 &
\end{tabular}

\section{Management of resistance}

Two treatments were conducted in commercial vineyards ('Sauvignon' cv.):

- a preventive application of the fungicides as treatments to keep populations permanently low; a forecast model and a threshold population is used to determine the spray timing (usually this means that many sporulating lesions (occupying up to $5 \%$ of the foliar area) are exposed to the fungicide) and use the fungicide only in tank mixtures or pre-packs with one or more different mode of action as that are known to control the resistant pathogen;

- an eradicative application of the systemic fungicides with the purpose off cure existing infections, when a certain, economically acceptable, amount of disease has already appeared, to prevent further spread. In addition, parts of the vineyard were not treated at all and served as untreated control plots. Figure 1 shows a scheme of the experimental site in the slightly sloping vineyard (slope 5-6\%), consisting of nine rows (length $=100 \mathrm{~m}$ ) of grapevines trained to a Guyot system. Spacing between rows was $2.0 \mathrm{~m}$ and spacing be- 
tween vines was $1.0 \mathrm{~m}$. Three rows were treated as resistance strategy system (preventive), six rows were either treated non- strategy system (eradicative) or left untreated $(n=3)$.

Single plots area was $144 \mathrm{~m}^{2}$ and contained 72 individual grapevines. The area treated as a resistance strategy system was divided into three consecutive plots when assessing disease symptoms.

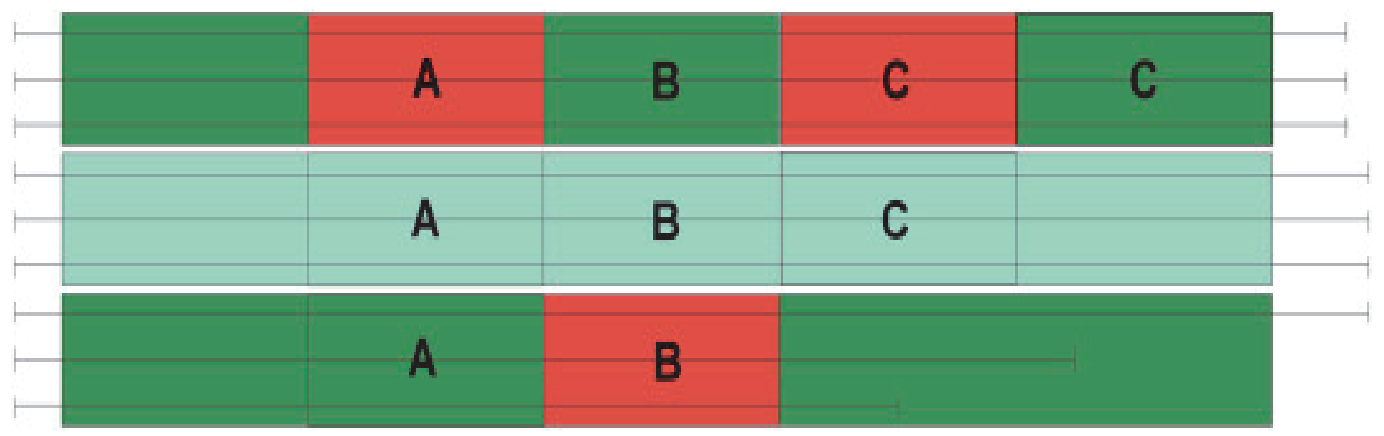

Figure 1. Setup of the field trial where treatments as preventive, were compared to treatments with the eradicative. Greenish plots = preventive; dark green plots = eradicative; red plots $=$ untreated control. A, B and C = replicates.

\section{RESULTS AND DISCUSSION}

The objective of this preventive strategy is to reduce selection pressure by:

1. Selecting and using fungicides correctly.

2. Managing the field in this way to be reduced the inoculum of the pathogen and create conditions less favorable for the disease to occur.

Meteorological conditions occurred leading to infection rates of fungal pathogens. The graph in Figure 2 shows the mean temperature and precipitation from the 15 th of April to the 15 th of September for the year of the field trials.

The viticultural year 2021 can be characterized as: favorable conditions for fungus development from the first decade of June and remains so until the end of the study. Data were recorded at the meteorological station of Valea Calugareasca, the Research Institute for Viticulture, located approximately $300 \mathrm{~m}$ from the experimental site.

In total, seven treatments were evaluated: three oxathiapiprolin combinations (oxathiapiprolin+folpet; oxathiapiprolin+zoxamide; oxathiapiprolin and folpet, co pack), at rates of $0.20+1.25 ; 0.5 ; 2.0 \mathrm{~L} / \mathrm{ha}$, respectively; folpet $80 \%$, at rate of $1.25 \mathrm{Kg} / \mathrm{ha}$; fluopicolid+fosetil$\mathrm{Al}$, at rate of $1.25 \mathrm{Kg} / \mathrm{ha}$; dimethomorph+mancozeb, at rate of $2.0 \mathrm{Kg} / \mathrm{ha}$; and NTC (untreated). Table 2 summarizes the data on disease severity on grapevine and fungicide efficacy in Valea Calugareasca in 2021. The reference product was Profiler 71,1 WG, applied at 3.0 $\mathrm{kg} / \mathrm{ha}$. The rate range was narrowed from active ingredient (a.i.) at 200+1600 to 85+85 g a.i. to an optimal effective rate of $20+1000 \mathrm{~g}$ a.i./ha. Within the optimum range $(20+1000 \mathrm{~g}$ a.i./ha). The results show that there was no significant difference in the efficacies of the tested fungicides Zorvec (98.1-98.4 \%) and Profiler 71.1 W G (95,9 and 97,2\%).

ANOVA indicated that fungicide treatments had a significant effect on incidence for all ratings at all locations $(P<0.0001)$. All treatments had a lower incidence than the NTC in the location. All treatments containing oxathiapiprolin (OXA) had statistically lower incidence and severity than all other treatments at the the second evaluation (86 DA-A) and all treatments. 


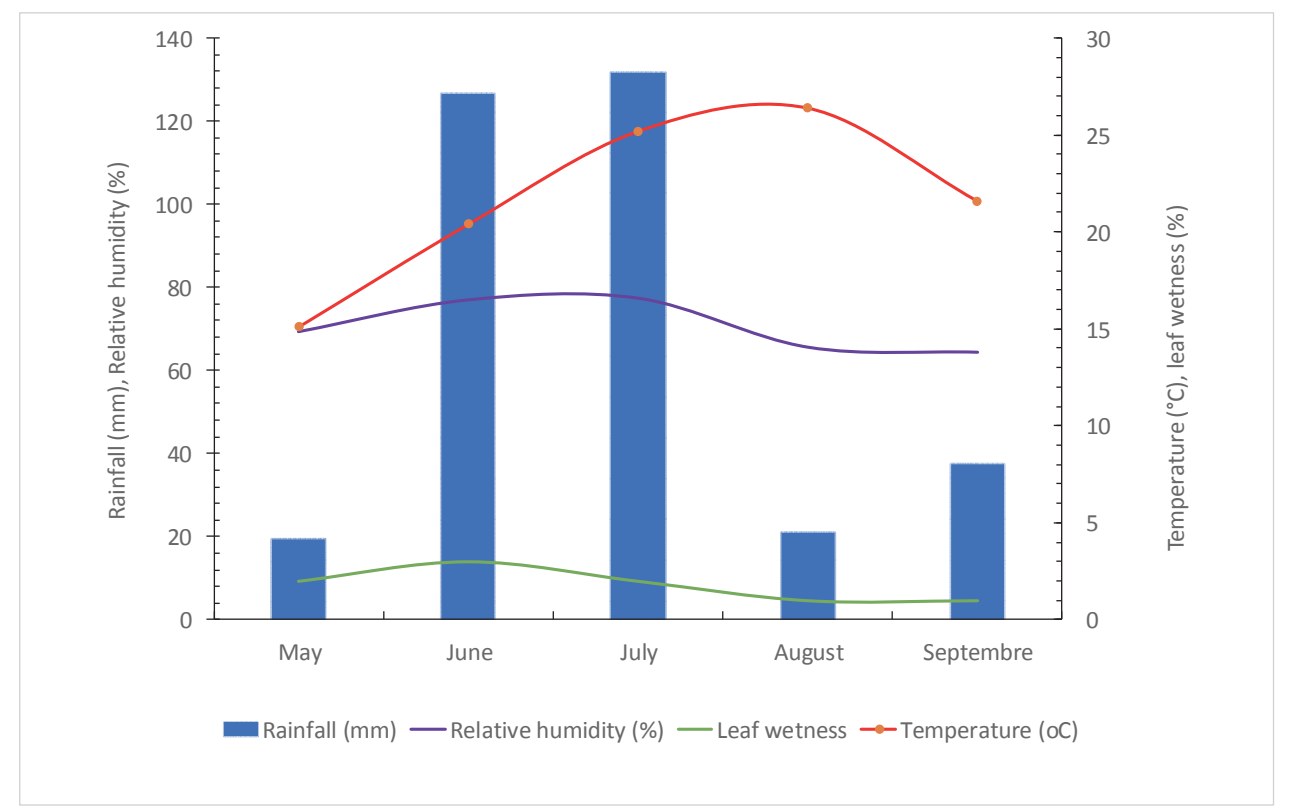

Figure 2. Mean temperature and precipitation in the field trial, 2021.

For the trial, the rate of OXA at $0.2 \mathrm{~L} / \mathrm{ha}+1.25 \mathrm{Kg} / \mathrm{ha}$ had a lower incidence than the NTC. No phytotoxicity was observed in any of the treatments containing fungicides. The results of this study demonstrate that the new fungicide compound, oxathiapiproline, significantly and consistently reduced downy mildew incidence under a wide range of disease pressure.

Table 2. Effects of fungicide treatments on incidence and severity at 86 DA-A, Valea Calugareasca. Mean values of four replicates are reported.

\begin{tabular}{|c|c|c|c|c|c|}
\hline \multirow[b]{2}{*}{ TREATMENT } & \multicolumn{2}{|c|}{ Leaves $\mathrm{x}$} & \multicolumn{2}{|c|}{ Bunches } & \multirow[b]{2}{*}{ Efficacy } \\
\hline & $\begin{array}{c}\text { Disease } \\
\text { incidence }\end{array}$ & $\begin{array}{l}\text { Disease } \\
\text { severity }\end{array}$ & $\begin{array}{c}\text { Disease } \\
\text { incidence } \\
\%\end{array}$ & $\begin{array}{c}\text { Disease } \\
\text { severity } \\
\%\end{array}$ & \\
\hline S5K22 510SC & $2.6 \mathrm{c}$ & $5.43 \mathrm{c}$ & $1.0 \mathrm{bc}$ & $5.00 \mathrm{~b}$ & 98.1 \\
\hline UBL47 340SE & $2.4 \mathrm{c}$ & $4.78 \mathrm{c}$ & $1.3 \mathrm{bc}$ & $5.00 \mathrm{~b}$ & 99.0 \\
\hline $\begin{array}{c}\text { QGU42 1000D (Zorvec) } \\
\text { + Folpan WDG }\end{array}$ & $3.6 \mathrm{bc}$ & $7.08 \mathrm{~b}$ & $1.5 \mathrm{~b}$ & $5.58 \mathrm{~b}$ & 97.7 \\
\hline Folpan WDG & $16.8 \mathrm{ab}$ & $24.70 \mathrm{ab}$ & $12.5 \mathrm{ab}$ & $15.34 \mathrm{a}$ & 68.1 \\
\hline Profiler 71,1 WG & $3.7 \mathrm{bc}$ & $7.15 \mathrm{~b}$ & $1.8 \mathrm{~b}$ & $5.45 \mathrm{~b}$ & 96.9 \\
\hline Acrobat MZ 69 WG & $5.0 \mathrm{bc}$ & $8.75 \mathrm{~b}$ & $1.5 \mathrm{~b}$ & $5.58 \mathrm{~b}$ & 88.9 \\
\hline NTC (untreated) & $62.3 \mathrm{a}$ & $18.75 \mathrm{a}$ & $25.0 \mathrm{a}$ & $17.83 \mathrm{a}$ & 0 \\
\hline LSD P $=.05$ & $1.81-21.39$ & 5.758 & 2.01 & $1.405-1.822$ & \\
\hline
\end{tabular}

${ }^{x}$ Percent incidence and severity was calculated as incidence (\%) = (number of infected leaves(bunches) / 100 leaves(bunches); Value in each column with different letters are statistically different at $p<0.05$ 


\section{Application of fungicides}

The experiment was performed in 2021. Experimental fungicide treatments began on May 25th, 2021, corresponding to BBCH 19 (9 or more leaves unfolded). The details of fungicide treatments (date, product name, rate, and active ingredient) to control downy mildew are listed in Table 3. The rates were those indicated by the manufacturer of the formulated products.

Table 3. List of tested treatments for downy mildew (active ingredients, dosages, period and number of applications)

\begin{tabular}{|c|c|c|}
\hline Product name & Rate/ha & Active ingredient \\
\hline Galben M & 2.5 & benalaxil + mancozeb \\
\hline Zorvec & 0.2 & oxathiapiprolin \\
\hline Equation Pro & 0.4 & cimoxanil + famoxadon \\
\hline Dithane M 45 & 2.5 & mancozeb \\
\hline Curzate F & 2.5 & cimoxanil+ folpet \\
\hline Folpan 80 WDG & 1.25 & folpet \\
\hline
\end{tabular}

Active ingredients of plant protection products against downy mildew differ in their plant mobility: they have systemic, translaminar, or contact-only properties. Fluopicolide belongs to a new chemical group of fungicides (acylpicolide), Leroux, (2002); fosetyl-Al has a complete systematicity, ascending and descending, (Müller et al., 2012); dimethomorph has a systemic function, (Ojiambo et al., 2010); folpet and mancozeb are organic compounds (Müller et al. 012; Gordon, 2010) with a broad-spectrum contact.

1. Select and use fungicides

a) Use of disease predictive models and scout field frequently to effectively time applications of fungicides. We had the services provided by an ADCON professional weather station with a downy mildew predictive model (Balaceanu et al., 2019) for early applications, being the most critical time to use at-risk fungicides. Figure 3 is an example of the high values of the sporulation and infection indexes of the pathogen in June.

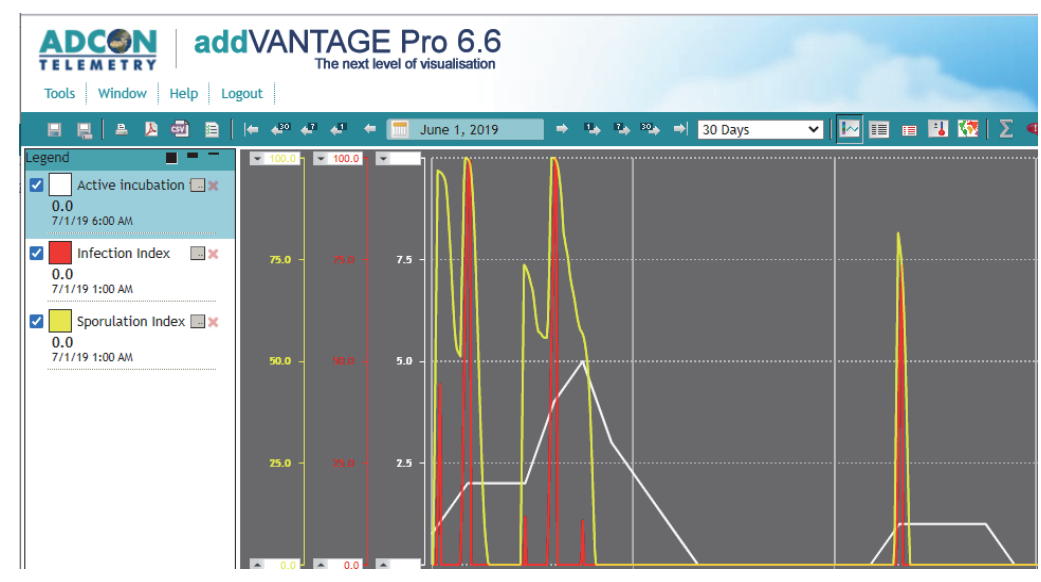

Figure 3. Downy mildew infection (red) and sporulation (yellow), Valea Calugareasca, 2021 
b) Application of the fungicides in combinations as a tank mix (Table 4) that provides multiple modes of action. The combination, composed of a high-risk (single-site) fungicide with a low-risk (multisite) fungicide has contributed to downy mildew resistance avoidance.

Table 4. Fungicides for the control downy mildew, Valea Calugareasca, 2021

\begin{tabular}{|l|c|}
\hline \multicolumn{1}{|c|}{ Active ingredient $\%$} & Total \\
\hline benalaxil 8\%+ mancozeb 65\% + other ingredients 27\% & $100 \%$ \\
\hline oxathiapiprolin 10\% + other ingredients 90\% & $100 \%$ \\
folpet 80 + other ingredients 20\% & $100 \%$ \\
\hline cimoxanil 30\% + famoxadon 22.5 + other ingredients 47.5\% & $100 \%$ \\
mancozeb 80\%+ other ingredients 20\% & $100 \%$ \\
\hline cimoxanil 4.8 + folpet 48\% other ingredients 47.2\% & $100 \%$ \\
\hline
\end{tabular}

c) Rotate fungicides with different mechanisms of action (Bosch et. al., 2011). Rotating fungicides has involved alternating products so that it avoids back-to-back treatments with anyone single-site fungicide or fungicides with a medium to high risk of resistance (Table 5). Medium to high risk fungicides (Group 4 and 11) were applied in a mixture or coformulation with an alternative mode of action, to ensure effective downy mildew control in these circumstances. The abbreviation BBCH (Lorenz et al. 1994) derives from the names of the originally participating stakeholders.

d) Apply labeled rates with adequate coverage of the foliage to produce good disease control. Following application, the field was monitored to determine how well the fungicide worked and for signs of any failure (table 6).

Table 5. Alternating product for downy mildew,Valea Calugareasca, 2021

\begin{tabular}{|c|c|c|c|c|}
\hline $\begin{array}{l}\text { Application } \\
\text { Data/BBCH }\end{array}$ & $\begin{array}{l}\text { FRAC } \\
\text { Code }\end{array}$ & $\begin{array}{l}\text { Chemical } \\
\text { group }\end{array}$ & $\begin{array}{c}\text { Active } \\
\text { ingredient }\end{array}$ & $\begin{array}{c}\text { Risk of } \\
\text { resistance }\end{array}$ \\
\hline $26.05 / 19$ & $\begin{array}{l}+ \\
\text { M3 }\end{array}$ & $\begin{array}{c}\text { acylalanines }+ \\
\text { dithiocarbamates }\end{array}$ & $\begin{array}{l}\text { benalaxil + } \\
\text { mancozeb }\end{array}$ & $\begin{array}{l}\text { high risk }+ \\
\text { low risk }\end{array}$ \\
\hline $8.06 / 55$ & $\begin{array}{l}49 \\
\text { M4 }\end{array}$ & $\begin{array}{l}\text { piperidinyl thiazole isoxazoline; } \\
\text { phthalimides }\end{array}$ & $\begin{array}{l}\text { oxathiapiprolin } \\
\text { folpet }\end{array}$ & $\begin{array}{l}\text { medium to } \\
\text { low risk }\end{array}$ \\
\hline $24.06 / 69$ & $\begin{array}{l}49 \\
\text { M4 }\end{array}$ & $\begin{array}{l}\text { piperidinyl thiazole isoxazoline; } \\
\text { phthalimides }\end{array}$ & $\begin{array}{l}\text { oxathiapiprolin } \\
\text { folpet }\end{array}$ & $\begin{array}{l}\text { medium to } \\
\text { low risk }\end{array}$ \\
\hline $5.07 / 73$ & $\begin{array}{c}27+ \\
11 \\
\text { M3 }\end{array}$ & $\begin{array}{c}\text { cyanoacetamide-oximes +Qol- } \\
\text { fungicides; } \\
\text { dithiocarbamates }\end{array}$ & $\begin{array}{l}\text { cimoxanil + } \\
\text { famoxadon } \\
\text { mancozeb }\end{array}$ & $\begin{array}{l}\text { low to } \\
\text { medium }\end{array}$ \\
\hline $16.07 / 75$ & $\begin{array}{c}27+ \\
\text { M4 }\end{array}$ & $\begin{array}{c}\text { cyanoacetamide-oximes + } \\
\text { phthalimides }\end{array}$ & $\begin{array}{l}\text { cimoxanil+ } \\
\text { folpet }\end{array}$ & $\begin{array}{l}\text { low to } \\
\text { medium }\end{array}$ \\
\hline $31.07 / 79$ & $\begin{array}{l}+ \\
\text { M3 }\end{array}$ & $\begin{array}{c}\text { acylalanines }+ \\
\text { dithiocarbamates }\end{array}$ & $\begin{array}{l}\text { benalaxil + } \\
\text { mancozeb }\end{array}$ & $\begin{array}{l}\text { high risk }+ \\
\text { low risk }\end{array}$ \\
\hline
\end{tabular}


2. Manage the experimental field by cultural practices to reduce the pathogen population or create conditions less favorable for the pathogen to develop and monitor and maintain agronomic factors such as soil moisture and crop nutrition, and manage other pests, to avoid crop stress throughout the season. Treatment descriptions are reported in Table 9.

Symptoms of downy mildew were assessed at the end of the spraying season in each plot. Mean values $(n=3)$ of disease incidence and severity are reported, in Table 7 , are most susceptible to downy mildew infections had already started. Disease incidence and severity of treatments using the preventive and eradicative methods, untreated, were notable.

Table 6. Dates, product names, rates, and active ingredients of fungicide treatments

\begin{tabular}{|c|c|c|}
\hline Product name & $\begin{array}{c}\text { Rate } \\
\text { L; kg/ha }\end{array}$ & Active ingredient \\
\hline Galben M & 2.5 & benalaxil 8\% + mancozeb $65 \%$ \\
\hline Equation Pro & 0.4 & cimoxanil 30\% + famoxadon 22.5 \\
\hline Zorvec & 0.2 & oxathiapiprolin $10 \%$ \\
\hline Curzate F & 2.5 & cimoxanil $4.8+$ folpet $48 \%$ \\
\hline Folpan WDG & 1.25 & folpet $80 \%$ \\
\hline Dithane M 45 & 2.5 & mancozeb $80 \%$ \\
\hline
\end{tabular}

The fungus attacks all green parts of the vines. It is currently controlled by repetitive fungicide treatments throughout the season, where the average number of fungicide treatments against downy mildew was equal to 6 in 2021. Experimental treatments started on May 26, 2021, (BBCH 19-9 or more leaves unfolded).

Table 7. Infection of grapevines with downy mildew comparing the two different applications methods and the untreated control, 2021. Mean values of three replicates are reported

\begin{tabular}{|c|c|c|c|c|}
\hline \multirow{2}{*}{$\begin{array}{c}\text { Application } \\
\text { Method }\end{array}$} & \multicolumn{2}{|c|}{$\begin{array}{c}\text { Infection of } \\
\text { leaves [\%] }\end{array}$} & \multicolumn{2}{c|}{$\begin{array}{c}\text { Infection of } \\
\text { bunches [\%] }\end{array}$} \\
\cline { 2 - 5 } & Incidence & Severity & Incidence & Severity \\
\hline Preventive & $29.2 \mathrm{a}$ & $3.7 \mathrm{a}$ & $0.3 \mathrm{a}$ & $0.0 \mathrm{a}$ \\
\hline Eradicative & $24.4 \mathrm{a}$ & $3.3 \mathrm{a}$ & $1.5 \mathrm{a}$ & $0.1 \mathrm{a}$ \\
\hline Untreated control & $81.8 \mathrm{~b}$ & $15.7 \mathrm{~b}$ & $14.4 \mathrm{a}$ & $0.9 \mathrm{~b}$ \\
\hline p-value & 0.000 & 0.017 & 0.082 & 0.020 \\
\hline
\end{tabular}

Numbers followed by the same letter in the same column are not significantly different (ANOVA followed by Tukey's HSD post hoc test. $p \leq 0.05)$. Ev.date Aug. the 1st (BBCH 79)

At that phenological stage, the period when leaves and bunches were compared. However, rainy weather conditions during the summer of 2021 led to a downy mildew infection of the leaves in the control plot and the plots were treated with preventive and eradicative methods (mean disease severity of $29.2 \%$ and $24.4 \%$, respectively). The untreated accounted for a mean disease severity of $81.8 \%$. Both strategy and no -strategy resistance lead to a nearly full protection of grapes, showing that applying plant protection products can protect leaves and bunches with comparable effects as when using fungicides. 


\section{CONCLUSIONS}

- Application of fungicides Zorvec+Folpan $80 \mathrm{WDG}$ at the rate of $0.2+1.25 \mathrm{~kg} / \mathrm{Ha}$, co pack, is effective and provided $97.7 \%$ disease control at values close to the standard fungicide (Profiler 71,1 WG), currently available to grapevine (96.9\%) disease control.

- Based on this study, two preventive applications per crop growing season of oxathiapiproline significantly and consistently reduced downy mildew incidence under a wide range of disease pressure. This fungicide should be used as part of an integrated control strategy, incorporating resistant of cultivars and prudent cultural practices.

- The spray should be started on the appearance of the disease symptoms, especially if weather conditions are conducive to the development of the disease. The use of the fungicide is only in tank mixtures or pre-packs is a resistance-management practice with high efficiency.

\section{REFERENCES}

1.Bittner, R.J., and Mila, L.A. (2017). Efficacy and timing of application of oxathiapiprolin against the black shank of flue-cured tobacco. Crop Protect. 2017; 93:9-18. 10.1016/j.cropro.2016.10.019

2. Bosch, F., Paveley, N.D., Shaw, M.W., Hobbelen, P.H.F., Oliver, R. (2011). The dose rate debate: does the risk of fungicide resistance increase or decrease with dose? Rotation. Plant Pathology 60, 597-606

3. Balaceanu C., Suciu G., Balanescu M., (2019). Assessment of climate change effects on the viticulture using Adcon Telemetry Station, 1st International Symposium of Climate Change, Plovdiv

4.EPPO (1997). Guidelines for the efficacy evaluation of plant protection products: Plasmopara viticola - PP 1/31(2). In: Standards: Guidelines for the efficacy evaluation of plant protection products, 2, EPPO,

5.FRAC Code List (2017). Fungicide Resistance Action Committee.27. http://pmep.cce.cornell.edu

6.FRAC Code List (C)*2021: Fungal control agents sorted by cross resistance pattern and mode of action including coding for FRAC Groups on product labels), Fungicide Resistance Action Comitee, 361

7.Gordon, E. (2010). Captan and Folpet, Hayes' Handbook of Pesticide Toxicology (pp.1915-1949), DOI:10.1016/B978-0-12-374367-1.00090-2

8.Hewitt, W.B., and Pearson, R.C (1988). Downy mildew. In: Compendium of Grape Diseases (R.C. Pearson and A.C.Goheen, American Phytopathological Society, St. Paul, MN, pp 11-13.

9. Leroux, P. (2002). Classification des fongicides agricoles et resistance. Phytoma, La Defense des Vegetaux, 554.

10. Lorenz, D.H., K.W. Eichhorn, H., Bleiholder, R., Klose, U., Meier, E., (1994). "Phänologische Entwicklungsstadien der Weinrebe (Vitis vinifera L. ssp. vinifera)". Vitic. Enol. Sci. 49: 66-7

11. Müller F., Ackermann p.,and Margot P. (2012). Fungicides, Agricultural, Individual Fungicides, Ullmann's Encyclopedia of Industrial Chemistry. Weinheim: Wiley-VCH. doi:10.1002/14356007.012_o06

12.Malavolta and Boller (2009). Guidelines for the integrated production of grapes, IOBC-WPRS Bull., 4613. Magarey P., 2010, Managing downy mildew, Plant pathology

13. Meier, (2001). Growth stages of mono-and dicotyledonous plants, U. Meier (Ed.), BBCH Monograph (second ed.), Federal Biological Research Centre for Agriculture and Forestry, p. 158

14.Müller F., Ackermann P., and Margot P. (2012). Fungicides, Agricultural, Individual Fungicides. Ullmann's Encyclopedia of Industrial Chemistry. Weinheim: Wiley-VCH. doi:10.1002/14356007.012_o06.

15. Ojiambo PS, Paul PA, and Holmes GJ. (2010) A quantitative review of fungicide efficacy for managing downy mildew Phytopathology. 100 (10): 1066-76. doi:10.1094/PHYTO-12-09-0348. PMID 20839942

16. Pasteris, R.J., Hanagan, M.A., Bisaha J.J., and Finkelstein B.L. (2016). Discovery of oxathiapiprolin, a new oomycete fungicide that targets an oxysterol binding protein. Bioorg. Med. Chem. 24 